Wilfrid Laurier University

Scholars Commons@ Laurier

Criminology

Laurier Brantford

Summer 2008

\title{
Trial by Jury in Russian Military Courts
}

Nikolai P. Kovalev

Wilfrid Laurier University, nkovalev@wlu.ca

Follow this and additional works at: http://scholars.wlu.ca/brantford_cc

\section{Recommended Citation}

Kovalev, Nikolai P., "Trial by Jury in Russian Military Courts" (2008). Criminology. 3.

http://scholars.wlu.ca/brantford_cc/3

This Article is brought to you for free and open access by the Laurier Brantford at Scholars Commons @ Laurier. It has been accepted for inclusion in Criminology by an authorized administrator of Scholars Commons @ Laurier. For more information, please contact scholarscommons@wlu.ca. 


\section{Nikolai P. Kovalev}

\section{Trial by Jury in Russian Military Courts}

Although de jure Russian legislation considers military tribunals as courts of the common jurisdiction (sudy obshchei iurisdiktsii) ${ }^{1}$, de facto Russian military courts constitute a separate system which is different from ordinary courts in several respects. Firstly, military courts try a special category of defendants, military personnel or citizens, who were called out for military training in military units (voennye sbory) ${ }^{2}$. Secondly, as opposed to judges in ordinary courts military judges are military officers, who have military ranks ${ }^{3}$ and wear military uniform, which means they have a more hierarchical organization and management. Thirdly, the jurisdiction of military courts does not correspond to jurisdiction of ordinary courts of the same level. There is one feature, however, which is shared by both courts for civilians and military personnel. It is the right to a jury trial for certain criminal cases. Russia is probably the only jurisdiction in the world which allows a jury of civilians to try criminal cases in military courts. Even in countries with matured jury systems, such as the United States, Canada and the United Kingdom, military personnel have no right to a jury of civilians. Instead, soldiers and officers of armed forces can be tried either by a single professional military judge or by a panel of officers and/or soldiers, which are sometimes called court-martial jury. This article focuses on the institution of jury in Russian military courts. The article consists of two main sections. The first section on history of lay participation intends to examine the development of lay participation in adjudication of crimes in Russian military courts. It is emphasized in this section that in the past the Russian government often restricted the power of lay judges to participate in adjudication of military crimes. The second part proceeds with the discussion on how civilian juries function in contemporary Russian military courts. In particular, it provides a critical analysis of the most recent decision of the Constitutional Court of the Russian Federation which suspended trial by jury in military courts in certain criminal cases. It is argued in the analysis that trial by jury should be made available to all military defendants.

Trial by jury in Russian military courts has not been sufficiently researched due to lack of transparency in military affairs in Russia. This article is the first attempt to study this institution from legal perspective.

\section{History of lay participation in Russian military courts}

The term lay participation in relation to military justice can be understood in two ways. Firstly, lay participation refers to the involvement of members of armed forces who are not educated or trained as professional judges into adjudicative process. Secondly, it refers to participation of civilians who are neither professional judges nor members of the armed forces. The first approach can be defined as trial by military peers and the second - as trial by civilians. In the past, both approaches were used in Russian military courts.

The earliest form of lay participation in Russia was the people's assembly (veche), which existed in the $11^{\text {th }}-13^{\text {th }}$ centuries in Kiev, Novgorod, Pskov and other Russian princedoms ${ }^{4}$. Originally, veches could try any case, but later the jurisdiction of the people's assembly was limited to political and state trials against the prince (kniaz') or the appointed governor (posadnik) $)^{5}$. There were cases when veche tried members of irregular army for refusing to participate in military operations. During military campaigns veche was comprised of all members of the army ${ }^{6}$. The significance of veches, and group decision-making in general, diminished after Novgorod and Pskov were incorporated in Muscovite Princedom and introduced a more authoritarian system of trial by the commander.

First military courts appeared in Russia only in the $17^{\text {th }}$ century when the dynasty of Romanovs came to power ${ }^{7}$. The Code of Law of 1649 (Sobornoe Ulozhenie) introduced the institution of the regimental judge (polkovoi sud'ia) who adjudicated low and middle ranks of the army ${ }^{8}$. It should be noted, however, that trial by military peers did not extinct in all provinces of the 
Russian state in the $16^{\text {th }}-17^{\text {th }}$ centuries. In the Don Cossacks Host (Donskoe kazach'e voisko) ordinary Cossacks had the privilege to be tried by the Cossack village circle (stanichnyi krug), which was similar to veche and included all equal between each other Cossacks who were able to carry weapons ${ }^{9}$. Those who were not satisfied with the decision of the Cossacks village circle could appeal to the Court of the Host Circle (Sud Voiskovogo Kruga), which was the highest instance for all Cossacks. ${ }^{10}$ This type of trial was practiced among Cossacks until the $18^{\text {th }}$ century when the central government in Moscow started to intervene into the Cossack selfgovernance by appointing permanent atamans ${ }^{11}$ and by transferring power from the village and Host circles to the appointed atamans and foremen ${ }^{12}$.

The system of military justice in Russia further developed and strengthened during the military reform implemented by Peter I in the beginning of the $18^{\text {th }}$ century. Peter I himself reviewed the new Military Code (Voinskii Ustav), which was adopted in 1715-1716. Part III of the Code "Short description of procedures and lawsuits" (Kratkoe izobrazhenie protsessov i sudebnykh tiazheb) was dedicated to issues of military court structure and procedure ${ }^{13}$. According to the Code, there were two types of military tribunals or Kriegsrechts (from German Kriegsrecht -law of war): Kriegsrecht-General (General'nyi Kriegsrecht) and regimental Kriegsrecht (polkovoi Kriegsrecht). Both tribunals were courts of first instance and while the first tried the most serious cases such as contempt of the King [Queen], state crimes, offences conducted by the entire or half of the regiment, battalion or company and criminal cases in which the defendant or victim was an officer of high rank. Other crimes were tried by the regimental Kriegsrecht ${ }^{14}$. Both types of military tribunals were collective in nature and could consist of thirteen members, but usually of seven members. Another significant difference between Kriegsrecht-General and regimental Kriegsrecht was composition. The Kriegsrecht-General consisted of only the highest ranks of the army: Field Marshal (fel'dmarshal), who was a president of the tribunal, and six assessors - two general-lieutenants (general-poruchik), two major-general (general-maior), and two brigadiers (brigadir) ${ }^{15}$ or colonels (polkovnik). The regimental Kriegsrecht was composed of more junior officers and included a colonel as a chairman of the court, and six assessors: two captains, two lieutenants (poruchik) and two ensigns (praporshchik) ${ }^{16}$. It should be noted that neither privates (soldaty) nor noncommissioned officers (unter-ofitsery) were qualified to serve as members of any Kriegsrecht, which means that these groups of military personnel had not the trial of their military peers, but rather a trial of their military superiors. Both Kriegsrechts were ad hoc courts formed to try a single matter. Military judges were not selected at random nor elected. Instead, the chairman of the court was always appointed by the higher commander (vysshee nachal'stvo) who could also appoint other members or assessors of the court. Alternatively, the chairman himself could choose assessors ${ }^{17}$. Members of the court had no education or training in legal matters, which was pointed out in the Code:

"Although it is common for all judges to know the laws and understand the truth, because who does not understand the truth cannot judge fairly, the Kriegsrecht works in different circumstances where there are only Officers, who cannot be required to have special skills in laws; because they spent all their time learning military skills and not legal ones."18

It should be also noted that there had been no formal higher legal education in Russia and even in civilian courts (grazhdanskie sudy) judges had not had a legal degree until 1750s when the first Russian university was opened ${ }^{19}$. For this reason the Code stipulated that the court should be assisted by the Auditor who should be "well-skilled in laws" and be a "good jurist". The tasks of the Auditor were to watch that the proceedings were conducted in an appropriate manner, intervene when the members of the Kriegsrecht departed from law and justice. The role of the Auditor in the Kriegsrecht can be compared to the role of the justice's clerk or a legal adviser in courts of the Justice of the Peace in England ${ }^{20}$. The function of the Auditor, however, was more than simply advise members of the Kriegsrecht on legal issues. The Auditor's responsibility was to ensure that the trial was fair for both the plaintiff (chelobitchik) and the defendant (otvetchik). Although the Auditor was not a judge of the Kriegsrecht, he was responsible for illegal judgement if he indulged to deliver such judgement ${ }^{21}$. 
The system of Kriegsrecht introduced by Peter I was the model of pure lay adjudication by military officers. Although the court was collective and included at least seven members, the system of selection of military judges did not guarantee that different views would be presented during deliberations since the president of the court could appoint loyal officers who would not challenge his opinion during deliberations. At the same time, the position of the legally trained Auditor was very important for ensuring that the proceedings were conducted in an impartial manner and in accordance with law. This type of military court had existed in Russia until 1860s when it was replaced by the model of mixed court of professional and lay military judges.

The Great Reforms of Tsar Alexander II drastically changed the whole judicial system of Russia by abolishing class courts (soslovnye sudy) which existed for different social classes and by introducing new institutions in criminal justice system such as professional bar, justice of the peace, and trial by jury ${ }^{22}$. Russia also reformed its military courts. The new statutes on military tribunals were introduced in May 1867. The Statute on Army Courts (Voenno-Sudebnyi Ustav) ${ }^{23}$ introduced a new system of tribunals for armed forces. Another law, the Statute on Naval Courts (Voenno-morskoi Sudebnyi Ustav) ${ }^{24}$ introduced courts for naval forces. Both statutes had almost identical texts and introduced a three-tier judicial system. The lower level courts were Regimental Courts (Polkovye Sudy) for armed forces and Equipage ${ }^{25}$ Courts (Ekipazhnye Sudy) for the Navy. The second tier of military court included Army-District Courts (Voenno-Okruzhnye Sudy) for armed forces and Naval Courts (Voenno-morskie Sudy) for the Navy. The third level of military courts, which functioned as appellate courts were Supreme Army Court (Glavny Voennyi Sud) for armed forces and the Supreme Naval Court (Glavnyi Voenno-morskoi Sud) for the Navy ${ }^{26}$. Lay participation was used only in military courts of lower and intermediate levels while the high military courts consisted exclusively of professional judges. Military courts of lower level, Regimental Courts and Equipage Courts, were composed of temporary lay judges selected from officers of the regiment or equipage in which the tribunal was established. The president of the Regimental and Equipage Courts was appointed by the commander of the part of the army which the regiment belonged to or the commander of the equipage from field grade officers ${ }^{27}$ (shtaboficers) to serve a one-year term. The commander also appointed two company grade or junior officers $^{28}$ (ober-oficers) to sit together with the president for a six-month term. In order to qualify for a member of the Regimental or Equipage Court the officer should not have any legal training but had to have at least two-years of front-line service experience. As in the Regimental Kriegsrecht, which was discussed earlier, soldiers and non-commissioned officers could not qualify for participation in adjudicative process in Regimental and Equipage Courts. Although military judges in regimental and equipage courts were released from the influence of legally trained clerk or auditor who assisted judges in regimental Kriegsrecht they were not absolutely independent from the supervision of regiment or equipage commander. Before the judgement of the regimental or equipage court came into force it had to be ratified by the commander of the regiment or equipage ${ }^{29}$. The commander of the regiment or equipage had the power not only to lessen the sentence of the convicted person but also appeal against the lenient sentence of the court to the Army-District Court or Naval Court.

Army-District Courts were established in each army district (voennyi okrug) and Naval Courts were established in each harbour (port). Besides the appellate functions Army-District Courts and Naval Courts also tried more serious felonies and all cases in which defendants were generals or company grade officers ${ }^{30}$. If regimental and equipage courts consisted of only lay judges, Army-District Courts and Naval Courts included both professional judges who were permanent members of the court and lay judges who were temporary members. Six temporary members were appointed either by the Commander of the Army-District or Commander of the harbour from officers: two field grade officers and four company grade officers. It is interesting to note that the ratio of field grade officers and company grade officers in Army-District Courts and Naval Courts was one to two, which was the same as in regimental and equipage courts. At the same time, qualification requirements for temporary members of Army-District and 
Naval Courts were much higher than for judges in regimental and equipage courts. Temporary members at Army-District Courts and Naval Courts should have at least eight years of military service experience, including at least four years front-line service experience or have been commanders of the unit (chast') for at least three years ${ }^{31}$.

Temporary members served a six-month term. The Statutes of 1867 for the first time in history of military courts in Russia introduced a system of rotation of lay judges. Temporary members at Army-District and Naval Courts could be re-appointed for a new term at least a year after they completed their service as a lay judge. The process of selection of lay military judges for Army-District and Naval Courts for each term was similar to the selection jurors in the $19^{\text {th }}$ century. There was a general list of candidates for Army-District and Naval Courts composed of representatives of regiments and equipages which were covered by the jurisdiction of the specific Army-District Court or Naval Court. In order to bring diversity of views into the adjudicative process and make the tribunal more impartial the Statutes of 1867 encouraged selecting military judges for each term from dissimilar combat arms (rody oruzhiia) for ArmyDistrict Courts and branches of the Navy (rody morskoi sluzhby) for Naval Courts ${ }^{32}$.

As mentioned above, Army-District and Naval Courts tried cases in the form of a mixed court of at least one professional judge, who was always a chairman, and six lay military judges who deliberated and voted together ${ }^{33}$. The Statutes did not prescribe the maximum number of professional judges involved in a trial, which means that the impact of lay judges on the outcome of the case could vary. Since the verdict was decided by a simple majority vote in cases when there were three professional judges who unanimously voted for conviction only two out of six votes of lay judges were sufficient to reach a guilty verdict. At the same time the Statutes of 1867 contained a new provision according to which in cases of split votes the decision was in favour of the defendant ${ }^{34}$. This humanistic verdict rule was also adopted for jury trials in 1864 and later inherited by the Russian jury law in 1990s. Another rule which aimed to reduce the pressure of the chairman of the court and senior officers on voting by junior officers was the requirement that junior officers should vote first followed by opinion of the chairman. It is questionable, however, whether this rule was effective in preventing illegitimate pressure on junior members of the court since firstly, voting was done by an open ballot, and secondly, the law required the court to reach a unanimous decision. The system of military courts established by the reform of 1867 had existed until 1917 when it was first replaced by reforms of the Provisional Government and then by Bolsheviks. The Statutes of 1867 introduced two models of lay participation of military personnel: the model of pure lay participation in regimental and equipage courts and mixed court of professional judge(s) and lay military judges. There were several differences from the system of Kriegsrecht in terms of size, involvement of professional judges and period of service of lay members. However, the common feature of the Russian military justice was that soldiers and non-commissioned officers were completely excluded from the adjudicative process.

Issues of participation of non-lawyers in the administration of justice were key to the judicial reforms of the Provisional Government in 1917 and concerned not only courts of ordinary jurisdiction but also military tribunals. On the $17^{\text {th }}$ of April 1917 the Provisional Government signed the Law on the Organisation of Elected Regimental Courts. The new courts consisted of six regimental judges - three officers and three soldiers. Each company or detachment of the regiment elected two electors (representatives) from the soldiers of the company or detachment by secret ballot. A general meeting of electors elected six regimental judges by vote or lot as well as four alternate judges - two from the officers and two from the soldiers. The Law required three basic qualifications for candidates to judicial office: (1) eligibility to participate in election of electors or candidates to judicial office; (2) literacy; and (3) soldiers should be in service for more than one year during peace and more than three months during war $^{35}$. For the first time in the Russian history and perhaps in the history of the Continental Europe the Provisional Government introduced the institution of military jury (voennyi sud prisiazhnykh $)^{36}$. These military juries which were composed of the equal number of officers and soldiers tried most serious offences in military-circuit and army corps courts. The 
institution of the military jury was different from the Russian civilian jury in several aspects. As opposed to courts of ordinary jurisdiction, which consisted of three professional judges and twelve jurors, in military courts there was only one professional judge presiding and guiding military jurors with regard to questions of law. Another feature of military jurors was that they participated in sentencing together with the presiding judge if the jury found the defendant guilty $^{37}$.

According to Russian Vedomosti, a newspaper of the $19^{\text {th }}$ century, the main reasons for the introduction of jury into administration of military justice were serious defects in the old military court system ${ }^{38}$. For example, decisions of courts possessed no guarantee of independence, judgements were fast but they were not merciful or just, all court terms were short, there were significant limitations in calling witnesses and rights of defence were often curtailed. The system of military jury existed for a very short period of time and was abolished by Bolsheviks along with the civilian jury system and other "bourgeois" legal institutions, but lay participation of military personnel continued during the Soviet rule in the form of mixed courts. Moreover, after 1917 there were several periods in the Russian history when civilians were allowed to adjudicate military personnel.

During the first years of the Soviet rule military personnel were often tried by the same courts which heard cases of civilians: local courts (mestnye sudy), revolutionary tribunals (revoliutsionnye tribunaly) and circuit courts (okruzhnye sudy). Local courts consisted of one permanent judge and two lay assessors (zasedateli). They tried cases punishable by no more than two years of imprisonment. "Counter-revolutionary" crimes were adjudicated by revolutionary tribunals which consisted of one permanent judge and six lay assessors. Lay assessors were elected by Soviets of workers', soldiers' and peasant's deputies of different level. Other crimes were tried by circuit courts with participation of quasi-juries ${ }^{39}$. The new institution existed in the circuit court was a hybrid model of the jury and mixed court which consisted of a presiding judge and twelve people's assessors (narodnye zasedateli) selected in a manner similar to the selection of assessors by Soviets for lower courts. This hybrid model was very similar to the Swiss (Geneva) system of lay adjudication in which the presiding judge was allowed into the jury room and had a deliberative vote ${ }^{40}$. The Bolsheviks' model had another peculiar feature - the right of lay assessors to challenge the presiding judge at any time during the trial and impose a lesser punishment than stipulated by law or even release a convicted defendant with no penalty.

The first special military courts (voennye sudy) appeared only after the formation of the Red Army (Krasnaia Armiia) in 1918. In July 1918 the People's Commissariat on Military Affairs (Narodnyi komissariat po voennym delam) adopted the Regulation "On Front regimental (detachment) local courts" ${ }^{\text {"41 }}$. Once again the judicial power for some criminal cases was transferred from civilian courts to the courts which were composed of members of armed forces. Contrary to the method of appointment of lay assessors existed in Tsarist military courts and the system of indirect election of military jurors employed by the Provisional Government, the Bolsheviks' introduced a method of direct and secret election of lay military assessors by all members of the regiment. Although the method of direct election continued to exist in Soviet military tribunals as it will be discussed further, the election process did not provide for a fair and objective selection of lay assessors. Moreover, the jurisdiction of regimental local courts was limited only to cases punishable by the maximum of five years imprisonment ${ }^{42}$. More serious offences continued to be tried by revolutionary tribunals and circuit courts which consisted of civilians. Some Soviet and contemporary Russian historians of military courts, such as Zagorskii and Petukhov, expressed an opinion that civilian courts were not effective in adjudicating crimes committed in the army and that was the major reason why revolutionary military tribunals were established in $1919^{43}$. According to Zagorskii, for example, cases of military crimes had to be considered by such courts of justice which were composed of judges who had good knowledge of work and life of the army and navy, military regulations, orders, who had not only special legal education but also military training ${ }^{44}$. 
Judges in Revolutionary military tribunals or RMTs (revoliutsionnye voennye tribunaly) were selected in a less democratic way than in regimental local courts. Chairpersons and two members of revolutionary military tribunals were appointed and dismissed by respective Revolutionary Military Councils (Revvoensovet) in other words, by executive military authorities. The strict hierarchical system of accountability of RMTs to military executives was necessary for the execution of tough punitive policies and establishment of the strict discipline in the army. One of the peculiar features of the revolutionary military justice was that judgements of RMTs could not be appealed and had to be executed within twenty-four hours after the decision was announced ${ }^{45}$. The only exception was the death sentence, execution of which could be postponed and the case could be sent back for re-trial by the Revolutionary Military Councils of the Republic and the respective front ${ }^{46}$.

In 1922, shortly after the end of the Civil War, revolutionary military tribunals were renamed into military tribunals (voennye tribunaly) and existed under this name for seventy years until in 1992 the Russian Government restored their name of voennye sudy or military courts. During these seventy years, however, the composition and manner of selection of lay assessors changed several times in 1926, 1938, 1958 and 1980. The structure and composition of military tribunals were usually regulated not by the laws but by consecutive by-laws or regulations (polozhenie) "On military tribunals" of 1926, 1958 and 1980. According to these regulations, military tribunals of first instance consisted of three judges. The key difference between the composition of military courts, according to 1926, 1958 and 1980 regulations, was that under regulations of 1926 in addition to permanent judges the court might include temporary members (vremennye chleny) of the tribunal or lay assessors. In other words, under regulations of 1926 participation of lay assessors in military courts was optional. On the contrary, under the regulations of 1958 and 1980 two lay assessors (narodnye zasedateli) must always participate in adjudication ${ }^{47}$. Another difference between temporary members under the 1926 regulations and lay military assessors introduced by regulations of 1958 was the method of selection. While the lists of temporary members were composed by the department of propaganda (politupravlenie) of the military district and approved by a joint order of the commander of troops and the president of the military tribunal of the district ${ }^{48}$, lay assessors under the 1958 regulations were elected by servicemen of the military unit.

Moreover, the Law "On the Judicial System" of 1938 (Zakon o sudoustroistve) again introduced civilian lay assessors into the adjudicative process in military tribunals. Thus, according to Article 55 of the Law "people's assessors (narodnye zasedateli) elected by the territorial and regional councils of toilers' [workers'] deputies and by the supreme soviets of the constituent and autonomous republics shall be called upon to take part in judicial sessions of military tribunals" ${ }^{\text {"49 }}$. The territorial jurisdiction of the military tribunals did not match the constituencies of territorial and regional councils in the Soviet period and this structure remains in modern Russia. In practice, this means that the vast majority of people's assessors were selected from the territory or region where the courthouse was located. Other territories and regions which were covered by the jurisdiction of the military tribunal selected only supplementary assessors who were summoned for circuit sessions (vyezdnaia sessiia $s u d a)^{50}$. The practice of summoning lay people from different regions, which became one of the constitutional controversies and affected the right of military personnel to trial by jury in contemporary Russia, is discussed further in this article.

In 1958 the Soviet Government adopted new regulations on military tribunals which once again introduced mixed courts with participation of a permanent judge and two lay military assessors (narodnye zasedateli voennogo tribunala) ${ }^{51}$. As mentioned above these assessors were elected among military personnel by general assemblies of servicemen for the period of two years ${ }^{52}$. As opposed to the method of election by secret ballot used in 1918 the regulations of 1958 stipulated for the open ballot procedure (otkrytoe golosovanie) which in the context of the army hierarchy, strict discipline and supervision by the propaganda department meant full approval of candidates nominated by commanders. Obviously, in a way similar to appointment of people's assessors in civilian courts, lay military assessors were chosen from "the most 
disciplined and trustworthy" servicemen ${ }^{53}$, which in effect meant individuals most loyal to the communist party and commanding officers. Although the independence of military judges and lay assessors was proclaimed in the regulations of $1958^{54}$ it was undermined by the power of the superiors to take disciplinary actions against lay assessors if they decided to reach a verdict undesirable for commanders or communist authorities in the army. In 1980 the Soviet Government revised and amended the regulations of $1958^{55}$. In relation to the status of lay assessors new regulations stipulated a longer period of service of lay assessors of two and half years and introduced a system of recall election of lay assessors "who betrayed trust" ${ }^{\prime 56}$. Although the system of recall election in general is designed to make judges and other officials more accountable before voters or community in this particular case, it was intended for a more effective control by commanding officers and authorities. The process of recall election was also a mere formality due to voting by open ballot. The institution of military assessors had existed in Russia until 2000 when it was substituted by the system of civilian assessors. According to the Federal Law "On people's assessors of federal courts of general jurisdiction of the Russian Federation" ${ }^{\text {,57 }}$, lay assessors for military courts were selected at random from the same list of candidates which was used as a source for selecting lay assessors for ordinary courts. Civilian assessors were allowed to participate in administration of military justice at all levels of military courts: garrison military courts (garnizonnye sudy); district (naval) military courts and the Military Collegium of the Supreme Court of the Russian Federation. The institution of civilian lay assessors was in place for a short period of time and abolished by the new Code of Criminal Procedure in 2004.

One of the main reasons why the institution of civilian lay assessors did not survive was the dissatisfaction of legal community and civil society with the institution for its lack of impact, inability to protect the right of the accused to a fair trial and provide plurality of views during court deliberations. Although in theory, the Soviet and Russian law granted people's assessors authority equal to that of the presiding judge in adjudication, in practice, assessors were used merely to give an appearance of a democratic process and collective decision-making. As assessors had no legal training, they frequently sought advice from the judges with whom they sat, on all legal issues that would come before the court. There was no room for disagreement; few assessors dared to challenge the position of the presiding judge, and a single assessor who did had no affect on the case because all matters were decided by a simple majority vote of two versus one. People's assessors who often took the path of the least resistance in adjudication earned the nickname "kivaly", or "nodders"

\section{The right of military personnel to trial by jury in modern Russia}

Before considering whether Russian military personnel have the constitutional right to a trial by jury, it is useful to describe the current court structure of the Russian Federation in relation to the criminal military justice. Russia retains the Soviet three-level court system for both civilian and military defendants: (1) the lower level - town or raion courts for civilians, and garrison military courts for military personnel; (2) intermediate or second level - regional or provincial courts for civilians and district (fleet) military courts - for military personnel; (3) the higher level - the Criminal Chamber of the Supreme Court of the Russian Federation for civilians and the Military Chamber of the Supreme Court of the Russian Federation for military personnel. The lower level courts try the majority of criminal cases in a raion (district), town or garrison where the crime has been committed. The second level court is a court of appellate instance for courts of the lower level and first instance for some especially grave crimes, which have been committed in the region, province and military district (fleet). The Supreme Court is the court of appellate instance for courts of second level and a trial court for criminal cases where the defendant is a MP or a judge. Since lay assessors were abolished in 2004, currently, lay adjudicators in the form of jury sit only in courts of the second level, which are located in provincial or regional centres. The jurisdiction of juries is determined not on the basis of the gravity of the offence, but on the basis of the traditional jurisdiction of the provincial (oblast'), republican (respublika), regional (krai) or district military (fleet) courts. Although 
juries in both civilian and district military (fleet) courts try the same range of crimes, which include forty-six serious felonies ${ }^{59}$, the territorial jurisdiction of district military (fleet) courts does not always coincide with the jurisdiction of a single province, region or national republic, but usually covers several subjects of the Russian Federation. At present, there are three fleet (flotskii) courts and nine district military (okruzhnoi voennyi) courts in Russia ${ }^{60}$. Sometimes the territorial jurisdiction of district military courts coincides the boundaries of military districts (voennyi okrug) and federal districts (federal'nyi okrug) ${ }^{61}$ as it is the case, for example, with the North Caucasus District Military Court and the Far East District Military Court, which territorial jurisdictions coincide with the North Caucasus Military District and the Southern Federal District; and Far East Military District and Far East Federal District respectively. In other cases, military district can be divided between two district military courts. For example, the judicial authority in the Volga-Ural Military District is divided between the Volga District Military Court and the Ural District Military Court. The Siberian military district is also subdivided into jurisdictions of the East-Siberian District Military Court and the West-Siberian District Military Court.

Moreover, in addition to the territory of the Russian Federation, some district military and fleet courts have jurisdiction over the military personnel charged with crimes committed on the territory of foreign states where Russia has military bases, for example, the Third District Military Court has jurisdiction to try defendants who serve in Kazakhstan; the Moscow District Military Court has jurisdiction over defendants who serve in Transdnistria (the unrecognized state on the territory of Moldova); the North Caucasus District Military Court has power to try soldiers and officers serving in Armenia and on the Black Sea Fleet based in Ukraine; and the Ural District Military Court has jurisdiction over servicemen deployed in Tajikistan ${ }^{62}$. The facts that each district military (fleet) court has a judicial authority over a large number of provinces and can have extraterritorial jurisdiction raise a complex question of which territory should provide a pool of potential jurors.

Although there is no complete statistics available on the number of jury trials conducted in all military courts across Russia, it appears that jury trials in military courts are quite infrequent. According to the Supreme Court of the Russian Federation, in 2004 there were only 11 jury trials in all district military (fleet) courts. This figure can be compared with the total of 14,280 criminal trials conducted in all military courts that year ${ }^{63}$. However, there is some statistics on the number of jury trials conducted in a particular military court. Between 2003 and 2006 the North Caucasus District Military Court conducted 12 jury trials, at least two of which were re-trials. Five of these trials resulted in acquittals. In the period between January 2004 and September 2006 the Moscow District Military Court, with the jurisdiction covering 17 provinces of the Russian Federation as well as Russian military personnel deployed in the unrecognised state of Transdnistria (Prednestrov'e) ${ }^{64}$, heard nine jury trials in relation to 22 defendants resulting in 11 acquittals $^{65}$. In 2007 the Moscow District Military Court tried five cases with juries $^{66}$. The Far East District Military Court tried only three cases with juries in 2004, 2005 and 2008. The first jury trial which took place in the Far East District Military Court resulted in acquittal of three defendants, the second trial resulted in conviction of one and acquittal of another defendant, and the jury in the third trial found all four defendants guilty. It is also noteworthy, that some military courts, for instance, the Pacific Ocean Fleet Court, have not yet tried a single case with a jury ${ }^{67}$. Since there is no statistics on either the number of criminal cases eligible for trial by jury or the number of requests for jury trials from the military accused it is impossible to establish the percentage of actual jury trials in relation to the number of cases which can be tried by juries.

Similarly to civilian courts the most common offence tried by juries in military courts is aggravated murder. Depending on the victim all murder cases can be divided into three major groups: (1) cases where victims were allegedly killed by their co-servicemen; (2) cases where Russian military personnel were charged with murder of civilians during military operation in Chechnya; (3) cases where military personnel were accused of murder of civilians in territories with no military operations. 
The first type of cases involves killing of soldiers by their co-servicemen on the territory of military units. Usually in these cases the accused do not challenge the fact that they caused death of the victims. However, the defendants plead not guilty claiming self-defence against aggressive victims. Use of violent hazing by last year conscripts (dedy - granfathers) and officers against new junior conscripts, which is known in the Russian army as dedovshchina ${ }^{68}$ (literally means the "rule of the grandfathers"), is one of the main factors of suicides, assaults and fatalities in the army. Sometimes junior conscripts who are victims of hazing kill their offenders to defend themselves. This defence was used in at least three cases tried by juries in the North-Caucasus District Military Court ${ }^{69}$ and the Far-East District Military Court ${ }^{70}$. In two of these cases juries acquitted defendants on all murder charges and in one case convicted the defendant. The verdicts were appealed by the parties and the Supreme Court reversed the acquittals, but sustained the conviction.

Another type of cases involved killings of civilians during the military campaign of the Russian Federal government in Chechnya. There were at least two such cases ${ }^{71}$ which were tried by four different juries at the North-Caucasus District Military Court in 2004 and 2005 resulting in four acquittals. The Supreme Court quashed all the acquittals and after the Constitutional Court's decision of 6 April 2006, which is analysed below, the cases were re-tried by professional judges who convicted all the defendants and sentenced them to long terms of imprisonment. These cases and their impact on suspension of jury trials in North-Caucasus District Military Court are discussed further in this article.

The third group of jury trials involve military defendants charged with murder of civilians in other than Chechnya provinces of Russia. These crimes are not linked to military service and were allegedly committed by the defendants when they were off duty. The only reason for trying such cases in military courts is that the defendants were serving soldiers or officers at the time the crimes were committed. There were at least three such cases tried by juries in the Lenigrad District Military Court ${ }^{72}$, the North-Caucasus District Military Court ${ }^{73}$, and the Moscow District Military Court ${ }^{74}$. The Supreme Court reversed the acquittals and sustained the convictions in a way similar to other types of murder cases discussed above.

In addition to murder cases juries sometimes try other crimes, such as disclosure of state secrets $^{75}$ and bribe-taking ${ }^{76}$. As the appellate practice of the Supreme Court of the Russian Federation shows the highest court systematically reverses jury acquittals, but confirms jury convictions. This practice, however, is not peculiar only to military justice, but is a serious challenge for the Russian jury system in general ${ }^{77}$. Firstly, systematic reversals of acquittals and the unlimited power of the state to re-try the defendant many times for the same crime deprive the defendant of his or her right to a fair trial by the impartial and independent tribunal including the right to be acquitted by such tribunal. Secondly, by mass reversals of jury acquittals the state diminishes the importance of trial by jury as a safeguard against government oppression.

The right of the accused to trial by jury is stipulated in the Federal Constitution adopted at the national referendum in 1993. According to Article 20(2), trial by jury should be considered as a safeguard for a fair trial in criminal cases punishable by capital punishment: "Capital punishment may, until its abolition, be instituted by the federal law as exceptional punishment for especially grave crimes against life, with the accused having the right to have his case considered in a law court by jury" [italics added] ${ }^{78}$. Another constitutional provision is vaguer and states that "Anyone charged with a crime has the right to have his or her case reviewed by a court of law with the participation of jurors in cases stipulated by the federal law" [italics added $]^{79}$. The Constitution also declares that "in cases stipulated by federal law trials shall be held by jury" ${ }^{\prime 80}$. In other words, the scope of the right of the accused to a jury trial and the degree of lay participation in adjudication of crimes is determined by the Parliament.

As opposed to constitutions of some other countries, for example, Canada, which explicitly excludes trial by jury from the criminal military justice ${ }^{81}$, the Russian Constitution does not make such exception for military defendants. Moreover, as mentioned above, current Russian legislation considers military courts as part of courts of the common jurisdiction (sudy 
obshchei iurisdiktsii). Firstly, this means that both military and civilian courts are regulated by the same criminal procedure law. Such practice is different from, for example, Canadian, American and British systems, where there is a special criminal procedure legislation for military tribunals: the National Defence Act in Canada ${ }^{82}$, the Uniform Code of Military Justice in the U.S. ${ }^{83}$ and Armed Forces Acts and other statutes in the UK. ${ }^{84}$ Secondly, it also indicates that defendants in military courts should be entitled to the same rights which are enjoyed by civilians. At the same time, it could be argued that the Russian Constitution does not guarantee either military or civilian defendants the right to a jury trial except in cases which are punishable by the death penalty ${ }^{85}$.

The question arises, however, whether the Parliament or the Constitutional Court can deprive a group of military defendants of their right to trial by jury even in cases which are punishable by death penalty or otherwise eligible for jury trial in other civilian and military courts. In its recent decision (postanovlenie) No. 3-P of 6 April $2006^{86}$ the Constitutional Court decided that the North Caucasus District Military Court (Severo-Kavkazskii okruzhnoi voennyi sud) should not grant applications of military defendants for a trial by jury if the crimes with which defendants are charged were allegedly committed in Chechnya where trial by jury has not been introduced yet ${ }^{87}$.

The Constitutional Court provided several grounds for its decision. Firstly, according to the Constitutional Court, district military courts should summon jurors from permanent residents of that subject of the Russian Federation (province, region, national republic, autonomous district) where the crime was committed. If the court summoned jurors not from the subject of the Federation where the crime was committed it would violate the constitutional right of people living in the province where the crime was committed to participate in the administration of justice. Secondly, given the fact that trial by jury in Chechnya has not been established yet, granting this right to military defendants would put civilian defendants in an unequal position with military defendants.

It can be argued, however, that the rationale provided by the Constitutional Court for this decision is not persuasive for the following reasons. The first argument of the Constitutional Court that the jury must be summoned from the province where the crime was committed cannot be justified for military courts simply because the crime may take place not on the territory of any subject of the Russian Federation, for instance, on a naval ship in international waters or in the territory of the Russian military base abroad. As to the constitutional right of people to participate in administration of justice, it can be argued that the Russian Constitution does not grant this right. Two constitutional provisions of article 20 and 47 cited above only recognise the right of the accused to the trial by jury. As to the provision of Article 123, it does not explicitly state that participation of citizens as jurors in the administration of justice is their right and not merely a mode of trial. Instead, it simply states that "in cases stipulated by law the trial is conducted with participation of jurors". Even if the drafters of the Constitution intended to recognize this right they did not stipulate that there is an absolute right of citizens to participate in the administration of justice in all and only crimes committed on the territory of their residence. In other words, the Constitution neither guarantees that permanent residents of the specific province have the right to try all crimes committed in their province nor prohibits them from trying crimes committed in other provinces.

In some countries with developed jury systems, for example the United States, there is a rule that a crime should be tried by a "jury of the state and district wherein the crime shall have been committed" ${ }^{\prime 8}$ and such trial should be held "in the state where the said crimes shall have been committed" ${ }^{\prime \prime 9}$.

40 On the one hand, American state and district could be equivalent to the Russian subject of the federation (province, region, national republic) and raion respectively. On the other hand, however, the American rule is not relevant to Russian military courts. Firstly, this rule is only applicable to regular courts, which try civilians, and not to courts-martial which try cases without juries. As early as in 1866 in Ex parte Milligan the United States Supreme Court drew a clear distinction between rights of civilian and military defendants to the trial by jury: "this right [to trial by jury] - one of the most valuable in a free country - is preserved to 
everyone accused of crime who is not attached to the army, or navy, or militia in actual service" [italics added]. ${ }^{90}$ Secondly, in Unites States state and federal trial courts are located in each county which allows conducting trials in the same community where the crime took place. In the context of the Russian Federation, however, military defendants cannot always be tried by courts located in the same province or raion where the crime was committed, simply because there is only one permanent court for each military district or fleet, which has jurisdiction to try cases with participation of jurors. In order to conduct trials in the same province where the crime was committed the Russian Government should either open at least seventy new district military (fleet) courts $^{91}$ in all subjects of the Russian Federation, or judges of the district military (fleet) courts should have periodic sessions around the district, the practice which was used in England and Wales before $1971^{92}$ and known as Courts of Assize. Alternatively, the Russian government can shift the jurisdiction of district military (fleet) courts to garrison courts which are located in many Russian cities other than centres of military districts. Neither of these options, however, has ever been considered by the Russian government. Instead, district military (fleet) courts selected jurors either from the province where the court was sitting or from several provinces composing the district. The latter practice was deemed unconstitutional by the decision of the Constitutional Court of 6 April 2006. The second argument of the Constitutional Court concerning equality of civilian and military defendants is also not convincing. There is no doubt that civilian defendants who committed offences in Chechnya and are tried at the Supreme Court of Chechen Republic currently, are not able to exercise their constitutional right to be tried by juries. At the same time it would be erroneous to equalize civilian and military defendants who committed offences on the territory of Chechnya in depriving of their rights. As mentioned above, Russian district military (fleet) courts have extraterritorial jurisdiction over the Russian military personnel committing crimes not only on the territory of Russia, but also on the foreign soil or in international waters. For instance, in February - March 2004 the jury at the North Caucasus District Military Court tried and acquitted a military defendant ensign (praporshchik) A. who was charged with double murder of his co-servicemen Pogosian and A., attempted murder of Dovzhenko and injury of K. These alleged crimes took place in July 2003 on the territory of the military unit in the city of Gyumri, Armenia ${ }^{93}$. Although Armenia is not a part of the Russian Federation the trial took place in the City of Rostov-onDon, the capital of Rostov province where the district military court with jurisdiction over this unit was located. Moreover, the jurors were selected from residents of Rostov province. If the same crime had been committed not by a Russian serviceman but by a Russian civilian the outcome would have been different. Since there is no right for a trial by jury for Armenian citizens this would mean that Russian civilian would not be eligible for trial by jury and this would place him or her in an unequal position with military defendants. Furthermore, the jurisdiction of the North Caucasus District Military Court is not limited to the territory of Chechnya and covers twelve other subjects of the Russian Federation ${ }^{94}$, all of which introduced trial by jury as well as military personnel deployed at Russian military bases abroad. This means that in criminal cases tried by district military courts the factor which determines whether a trial by jury should be conducted is not the fact that the crime has been committed on the territory of a specific province, but rather the fact that the military defendant belongs to a certain military district. According to the Russian legislation military district is a primary military-administrative unit of the Russian Federation ${ }^{95}$ and for the purpose of military justice the government established district military courts.

The involvement of the Constitutional Court of the Russian Federation into the debate over the issue of territorial selection of juries for military courts was a result of repeated acquittals of military personnel accused of murder of Chechen civilians in two high-profile cases of Ulman et al. and Khudiakov \& Arakcheev. In the case of captain Ulman, lieutenant Kalaganskii, ensign Voevodin and major Pereleskii, on $11^{\text {th }}$ of January 2002 a reconnaissance unit under the command of captain Ulman was ordered to block the traffic on a road in Chechnya and check all vehicles as part of an operation targeting an Arab terrorist leader Khattab. One of the 
cars driving on the road did not stop and Ulman ordered his unit to machine-gun the car, which resulted in the killing of one passenger and injuring two out of five other civilians who had no weapons found in their possession. The Russian soldiers provided the injured with first aid and contacted their superior by radio. According to the defendants, they were given the order to kill all detainees. Although the defendants confessed to killing Chechen civilians, they pleaded "not-guilty" and chose trial by jury. It should be noted that the Russian criminal law does not recognise execution of an illegal order as a defence, unlike duress or necessity. Moreover non-compliance with an illegal order excludes criminal liability (Article 42 of the Criminal Code of the RF). According to the Russian law, felony cases of military defendants should be tried in a district military court by a jury selected from civilians. Chechnya, as a part of the South Western province of Russia is in the jurisdiction of the North Caucasus District Military Court located in the Russian city of Rostov-on-Don. The first jury, which was selected from the residents of Rostov province, unanimously acquitted all the defendants on the $29^{\text {th }}$ of April 2004. The prosecution and victims' relatives appealed to the Supreme Court on the grounds of procedural errors during jury selection and trial. In August 2004 the Supreme Court quashed the acquittals on the basis of breach of rules in compiling jury lists for the district military court in November 2003. For the second trial prospective jurors were summoned from several Southern provinces: Adygeia, Dagestan, Volgograd, Astrakhan', Stavropol', Krasnodar and Rostov provinces. None of these prospective jurors, however, were summoned from Chechnya where trial by jury is only to be introduced in 2010. The result of the new trial was the same - a unanimous not-guilty verdict for all the defendants on the $19^{\text {th }}$ of May 2005 . On the $30^{\text {th }}$ of August 2005 the Supreme Court of Russia once again quashed the acquittal on several grounds: jury selection was conducted in the absence of victims' relatives, who could not exercise their right to peremptory challenges and inappropriate jury instructions given by the judge. The presiding judge in his summation cited a passage from Matthew: "Judge not, that ye be not judged. For with what judgment ye judge, ye shall be judged", which could have been interpreted by some jurors as an invitation to nullify criminal law. In November 2005 the North-Caucasian district military court opened preliminary hearings of Ulman's third trial. However, it was suspended by the presiding judge due to a letter of inquiry submitted by the President of the Chechen Republic Alkhanov to the Constitutional Court of the RF which questioned whether the Law on Military Courts (Zakon "O voennykh sudakh"), according to which a military court can try cases by juries, is compatible with the federal Constitution. In April 2006 the Constitutional Court of the RF in its decision held that although the Law on Military Courts was compatible with the Federal Constitution, the North-Caucasian District Military Court tried the Ulman case by the wrong composition of juries.

In the case of Khudiakov and Arakcheev two officers of the Ministry of Internal Affairs of the Russian Federation, Evgenii Khudiakov and Sergei Arakcheev, were accused of murder of three Chechen men. According to the indictment, the officers blocked the road near Groznyi Airport in Chechnya and stopped a dump truck, which was carrying three Chechen construction workers. Khudiakov and Arakcheev ordered the three to get out of the vehicle and lie on the ground. Khudiakov then allegedly shot each of them in the head. The defendant denied all allegations and claimed an alibi defence. The first trial of Khudiakov and Arakcheev was held, like Ulman's case, in the North-Caucasus District Military Court with a jury selected from Rostov residents. At the trial, prosecution witnesses, who were soldiers from the unit of the defendants, changed their testimony and said that military investigators forced them to give false statements incriminating Khudiakov and Arakcheev in killing the Chechen civilians. The first trial resulted in a unanimous not-guilty verdict in June 2004. The prosecution appealed and in November 2004 the Supreme Court of the RF like in the first Ulman trial, quashed the acquittal on the ground that jurors were selected from an inappropriate jury list, which had expired on the date of selection. The second jury was selected in the manner similar to jury selection for the second Ulman trial, from residents of several Southern Russian provinces. The outcome of the second trial was the same - acquittal with only one out of twelve jurors having voted for a guilty verdict. The prosecution appealed again and the Russian Supreme Court quashed the jury acquittal in May 2006. 
The Constitutional Court has reached not merely a legal, but a political decision which aimed, firstly, to assuage Chechen community, and, secondly, to enhance the prestige of the new Chechen government, loyal to the Kremlin as an authority capable to protect Chechen interests. After this decision of the Constitutional Court both cases were tried by a court with professional judges only and resulted in convictions and long jail sentences for all defendants. Two very different verdicts by juries and professional courts aroused concern over jury bias in cases where the Russian military personnel were accused of murder of Chechen civilians. Although neither the Supreme Court of the Russian Federation nor the Constitutional Court has ever mentioned this concern in their decisions some journalists, human rights activists, and public figures condemned jury acquittals in these cases as ethnically motivated.

The question whether jury verdicts in these two trials were unfair and biased deserves a separate examination. However, the decision to remove civilians from military courts for political reasons undermines fair trial right of the military personnel to be tried by an impartial and independent court. For instance, the European Court on Human Rights held in Cooper v. $U K$ that "the presence in a court-martial of a civilian [...] constitutes not only an important safeguard but one of the most significant guarantees of the independence of the court-martial proceedings" ${ }^{96}$. Furthermore, all professional judges in Russia are appointed by the executive branch of power and military judges are also military officers, which makes them dependent on their superiors in relation to promotion and obtaining higher military ranks. This argument is supported by a prominent Russian scholar Stetsovskii, who also suggested that military justice should be abolished altogether and the status of all courts and judges should be equal ${ }^{97}$. Moreover, according to another Russian expert, Sergey Pashin, many military judges are former military investigators ${ }^{98}$, which implies that they have a strong accusatorial bias or a tendency to presume that the defendants are usually guilty. As result of the decision by the Constitutional Court, other military defendants accused of crimes committed in Chechnya lost their chance to be acquitted. According to statistics available for all courts of common jurisdictions (civilian and military courts) in the Russian Federation the acquittal rates in bench trials differ significantly from the acquittals rates in jury trials. Thus, in 2007 there was a total of 4,300 criminal trials held in courts of provincial level or courts which can hear criminal cases with juries. These criminal cases were heard in relation to 7,333 defendants. Out of 4,300 criminal cases the number of jury trials was 522 in relation to 1,142 defendants. The total number of bench trials in courts, which can hear cases with juries, was 3778 and the number of defendants tried only by professional judges was 6,191 . The number of acquitted defendants in bench trials was 83 and the number of acquitted in jury trials was 236, which constituted an acquittal rate of $1.3 \%$ for bench trials and $20.6 \%$ for jury trials $^{99}$. It is also noteworthy that after the decision of the Constitutional Court in April 2006 none of the cases in the North-Caucasus District Military Court was tried with participation of jurors in 2006 and 2007.

Another issue of importance is whether the Russian military personnel charged with murder of Chechen civilians can have a fair trial with a jury selected from the residents of Chechnya. Although the Constitutional Court of the Russian Federation in its decision of 6 April 2006 did not recognize that juries in Ulman trials were prejudiced against the Chechen victims, the Court, however, pointed out that "the selection of jurors from citizens, who are not residents of the province... where the crime was committed would create risk of arbitrary selection of jurors for the particular case and as a result would not provide a fair trial by an impartial tribunal". In support of this argument the Constitutional Court referred not only to the Russian Constitution, but also to the European Convention on Human Rights, International Covenant on Civil and Political Rights and the Universal Declaration of Human Rights. On the one hand, this argument of the Constitutional Court appears plausible. On the other hand, the argument and its reference to the right to a fair trial guaranteed by the international human rights instruments are not very relevant to trials of Russian military personnel charged with murder of the residents of Chechnya. There are two reasons for this. First of all, it is highly doubtful that jurors selected from the residents of Chechnya would be impartial towards Russian soldiers and officers, especially those who are not members of the Chechen community. According to 
the most recent national census in the Russian Federation in 2002, ethnic Chechens constituted $93 \%$ of total population ${ }^{100}$. Moreover, it is widely known that the attitude of Chechens towards the Russian military is generally negative ${ }^{101}$. As one Russian journalist noted "taking into account that the population of Chechnya is predominantly Chechen the outcome of the trial is $100 \%$ predictable, and it would leave no chance of being acquitted even for those defendants who have been framed"102. Indeed if the Constitutional Court argues that a non-Chechen jury cannot be impartial in cases where Russian soldiers are accused of murder or other crimes against Chechens, it is even fairer to assume that an all-Chechen jury would have an equally strong bias against Russian military personnel. This would cause Russian soldiers and officers accused of crimes committed in Chechnya to waive their right to trial by jury and opt for a military bench trial, even though it would not provide higher chances of acquittal than an allChechen jury.

The second reason why the reference of the Constitutional Court to the international human rights law, and in particular to ECHR, ICCPR and UDHR, is not only irrelevant but also fallacious is that provisions of Article 6(1) of ECHR and Article 14(1) of ICCPR concern the right of the accused to be tried by an independent and impartial tribunal. Article 6(1) of ECHR states: "In the determination of his civil rights and obligations or of any criminal charge against him, everyone is entitled to a fair and public hearing within a reasonable time by an independent and impartial tribunal established by law" [italics added] ${ }^{103}$. Similar clauses can be found in Article 14(1) of ICCPR: "In the determination of any criminal charge against him, or of his rights and obligations in a suit at law, everyone shall be entitled to a fair and public hearing by a competent, independent and impartial tribunal established by law" [italics added] ${ }^{104}$ and Article 10 of UDHR: "Everyone is entitled in full equality to a fair and public hearing by an independent and impartial tribunal, in the determination of his rights and obligations and of any criminal charge against him" [italics added] ${ }^{105}$.

Russian military defendants in Ulman et al. and Khudiakov and Arakcheev have never argued that selecting jurors not from the residents of Chechnya violated their right to a fair trial by an impartial tribunal. On the contrary, there is a greater risk that a jury selected from the residents of Chechnya would be biased against the defendants and hence undermine their right to be tried by an impartial court. To some extent this hypothesis is acknowledged by victims' lawyers in Ulman et al. For instance, Liudmila Tikhomirova believes that if the jury was composed of residents of Chechnya who are, for obvious reasons, out of sympathy with the federal military personnel who served in Chechnya as the majority of all other Russian citizens the verdict would be different ${ }^{106}$.

51 Furthermore, some jurisdictions ${ }^{107}$, including the Russian Federation in special cases allow transferring the trial to another jurisdiction or court. This practice is called change of venue. The reason for moving the trial to a new location is usually the presence of a great danger of prejudice among residents of the region where an alleged crime has been committed against the accused due to the widespread publicity about the crime or/and the defendant. Hence, the main purpose of change of venue is choosing jurors who lack exposure to prejudicial information about the crime or/and the defendant and whose interests are not infringed by the trial. The decision of the court to transfer a trial to a new location due to possible prejudice against the accused is usually made upon the defense's motion ${ }^{108}$. For instance, in the U.S. in federal courts, the prosecution does not have a similar right since it would contradict the defendant's constitutional right to be tried by a jury selected from the district where the offense was committed $^{109}$. In recent years change of venue has been used in such high-profile jury trials as first Virginia trials of John Allen Muhammad and Lee Boyd Malvo, defendants in a case also known as D.C. sniper case ${ }^{110}$, and a trial of Oklahoma City bomber Timothy McVeigh ${ }^{111}$. The Russian criminal procedure law also recognizes the possibility of moving the trial to another jurisdiction. Article 35 of the Code of Criminal Procedure states inter alia that territorial jurisdiction of the criminal case can be changed upon the party's motion if the party's challenge to the entire composition of a court was successful ${ }^{112}$. Although this provision does not explicitly regulate the issue of jury prejudice, Pashin has argued that the prosecution could 
use it as legal grounds for transferring the trial by jury to another court district (sudebnyi okrug) in first trial of Ulman et al. ${ }^{113}$ In a similar manner this argument could be applied to cases of Russian military defendants accused of crimes committed in Chechnya where the defence requested to move a trial from Chechnya to another jurisdiction.

Therefore the Constitutional Court's argument that the transfer of trial by jury from one jurisdiction to another would violate international and domestic laws is erroneous. On the contrary, change of venue is a procedural device used in jurisdictions with matured jury systems as a measure to guarantee the defendant's right to a fair trial by an impartial tribunal.

\section{Conclusion}

Lay participation in the administration of justice in Russian military courts has a long and controversial history. With the exception of ancient democratic institutions of veche existed in some Russia provinces until the $16^{\text {th }}$ century and Cossack circles convened by Russian Cossacks until the $18^{\text {th }}$ century, military courts in Russia did not function in an independent and impartial manner. This was largely due to military judges being a part of the military hierarchy. Although during some periods of the Soviet history, the government allowed civilians to adjudicate cases involving military defendants, their impact on the criminal military justice was minimal due to missing judicial independence from the executive branch of power. The introduction of trial by jury in Russian military courts in 2004 gave military defendants the chance to have a fair trial by independent and impartial tribunal. However, mass reversal of jury acquittals by the Supreme Court of the Russian Federation ${ }^{114}$ and the decision by the Constitutional Court of the Russian Federation of April 6, 2006 deprived many military defendants of their right to a fair trial which is declared in the Constitution. Although the issue of bringing war criminals to justice is vital for peace and reconciliation process in Chechnya, it should not undermine the rights of defendants. The introduction of trial by jury in Chechnya is crucial for completion of jury reform in Russia. However, the Federal Government needs to guarantee Russian military personnel charged with crimes allegedly committed in Chechnya the right to a fair trial, including their right to an impartial and independent jury. In particular, the Government might clearly stipulate in the Code of Criminal Procedure provisions allowing change of venue and selection of juries from residents of different provinces in cases where there are serious doubts about impartiality and independence of the jury.

\section{Notes}

1 Federal'nyi konstitutsionnyi zakon "O voennykh sudakh Rossiiskoi Federatsii" (the Federal Constitutional Law "On Military Courts of the Russian Federation") [FCL On Military Courts] \# 1-FKZ of 23 June 1999, art. 1.

2 Ugolovno-protsessual'nyi kodeks Rossiiskoi Federatsii (Code of Criminal Procedure of the Russian Federation) [hereinafter CCP RF] \# 174-FZ of 18 Dec. 2001 (with amendments as of 6 Dec. 2007), art. 31(5)-31(6).

3 According to Appendix to the FCL On Military Courts the lowest rank for a military judge is the lieutenant colonel of justice (podpolkovnik iustitsii). It corresponds with the rank of judge at the garrison military court (garnizonnyi voennyi sud), lower military court. The highest rank in military judiciary is colonel-general which is the rank of the Chairman of the Military Collegium of the Supreme Court of the Russian Federation. It should be noted, however, that in March 2008 the Russian Government introduced a bill to the State Duma (the lower house of the Russian Parliament) which would suspend military service of judges in all military courts. This would deprive military judges of their Ministry of Defence benefits and ranks. Proekt Federal'nogo konstitutsionnogo zakona "O vnesenii izmenenii v Federal'nyi konstitutsionnyi zakon "O voennykh sudakh Rossiiskoi Federatsii", \# 25824-5. http://www.duma.gov.ru/.

$4 \mathrm{~K}$. Trotsina, Istoriia sudebnykh uchrezhdenii v Rossii, Tipografiia Eduarda Veimara, SanktPeterburg, 1851. http://allpravo.ru/library/doc313p0/instrum3134/. Accessed 7 Jan. 2008. Veche in Old Russian (from verb veshchat'- speak publicly) is any meeting, private or open, at the square or at the yard. M.F. Vladimirskii-Budanov, Obzor istorii russkago prava, izd- 
e 6, Izdanie knigoprodavtsa N.Ia. Ogloblina, S.-Peterburg- Kiev, 1909, p. 51. In this case, however, the term veche is used solely with regard to a judicial assembly.

5 Vladimirskii-Budanov, supra note 4 at 60. K.A. Sofronenko, Istoriia gosudarstva i prava SSSR. Chast 1. Iuridichaskaia literatura, Moskva, 1967, p. 191.

6 N.A. Petukhov, Istoriia voennykh sudov Rossii, Moskva: Izd-vo Norma, 2003, pp. 15-16.

7 Ibid. p. 22.

8 M.N. Tikhomirov, P.P. Epifanov, Sobornoe Ulozhenie 1649 g., Moskva: Izd-vo Moskovskogo universiteta, 1961, p. 87, 127 (Ch. VII, art. 26; Chapter. X art. 149).

9 A.V. Venkov, Sistema upravleniia i samoupravlenia, in Ocherki traditisonnoi kul'tury kazachestv Rossii, vol. 1, Moskva-Krasnodar, 2002, pp. 328-329.

10 Venkov, p. 329.

11 Ataman was an elected leader and commander of Cossacks. There were different types of atamans: village ataman (stanichnyi ataman), Cossack Host ataman (voiskovoi ataman) etc.

12 Venkov, pp. 332-333.

13 K.A. Sofronenko, Pamiatniki russkogo prava, vypusk vos'moi, Zakonodatel'nye Akty Petra

I, Gosudarstvennoe izdatel'stvo iuridicheskoi literatury, Moskva, 1961, pp. 579-601.

14 Ibid. pp. 579-580.

15 According to Table of Ranks, a formal list of positions and ranks in government, military and court of the Russian Empire, introduced by Peter I in 1722 brigadier was an officer of $\mathrm{V}$ grade, rank junior to major-general and senior to colonel. G.A. Murashev, Tituly, chiny, nagrady. SPb: OOO Izd-vo Poligon, 2001, pp. 63, 75.

16 Sofronenko, p. 580.

17 Ibid., p. 581.

18 Ibid. pp. 580-581.

19 According to Kucherov [u]p to the end of the $18^{\text {th }}$ Century the faculty of law of the Moscow University remained the sole source of legal education in Russia". In order to prepare new professors among Russians Alexander I sent Russian students to the foreign universities for undergraduate and graduate studies. S. Kucherov, The Organs of the Soviet Administration of Justice: Their History and Operation, Leiden: E.J. Brill, 1970, pp. 251-257.

20 P. Darbyshire, "Raising Concerns about Magistrates' Clerks", in S. Doran and J. Jackson (eds.), The Judicial Role in Criminal Proceedings, Oxford: Hart Publishing, 2000, pp. 183-192.

21 Sofronenko, p. 581.

22 S. Kucherov, Courts, Lawyers and Trials Under the Last Three Tsars, New York: Praeger, 1953.

23 Polnoe sobranie zakonov Rossiiskoi Imperii [hereiafter PSZRI], sobranie 2-e, tom. XLII, 1867, Tipografiia II Otdeleniia sobstvennoi E.I.V. Kantseliarii, 1871, \# 44575, pp. 536-637. 24 Ibid. \# 44576, 637.

25 In the beginning of the $19^{\text {th }}$ Century the equipage system was introduced. The "equipages [was] a series of corps into which the entire naval force [was] divided. These [were] unites like small army corps - each containing its own ships, equipage commander, and officers and men of all ranks and ratings, including a treasurer and adjutant. Equipages [were] subdivided into companies under lieutenants, and each averages 150 men". By the beginning of the $20^{\text {th }}$ Century the Russian Navy had around thirty-three equipages. F.D. Jane, The Imperial Russian Navy, Conway Maritime Fleet, London, 1983, pp. 484-493.

26 PSZRI, XLII, pp. 536, 637.

27 Field grade officers in the Russian Army were officers of ranks of colonel, lieutenant colonel, or major, and in the Navy - captain (kapitan 1-go ranga), commander (kapitan 2-go ranga), or lieutenant commander (kapitan 3-go ranga). L.E. Shepelev, Otmenennye istoriie chiny, zvaniia i tituly v Rossiiskoi Imperii, Leningrad: Izd-vo "Nauka", 1977, pp. 25-26.

28 Company grade or junior officers in Russian military rank system were: captain, lieutenant, second lieutenant, or ensign in the army and lieutenant (kapitan-leitinant), sub-lieutenant (lieutenant), midshipman (michman), garde-marine (gardemarin) in the Navy. Ibid. 41-43.

29 PSZRI, XLII, pp. 566.

30 Ibid., pp. 590, 691-692.

31 Ibid., pp. 539, 640.

32 Ibid.

33 Ibid., pp. 594, 696. 
34 Ibid., pp. 604.

35 R.P. Browder and A.F. Kerensky, The Russian Provisional Government 1917. Documents. In three volumes, Stanford: Stanford University Press, 1961, Vol. II, p. 894.

36 Ibid. pp. 897-899.

37 Ibid. p. 898.

38 Ibid. pp. 899-900.

39 S.A. Golunskii, Istoriia zakonodatel'stva SSSR $i$ RSFSR po ugolovnomu protsessu $i$ organizatsii suda i prokuratury, 1917-1954 gg: sbornik dokumentov, Moskva: Gos. izd. iurid. lit-ry, 1955, pp. 40-44.

40 I. Zakrevskii, O nastoiashchem $i$ budushchem suda prisiazhnykh, S.-Peterburg: Tip. Soikina, 1897, pp. 84-185. I.Ia. Foinitskii, Kurs ugolovnogo sudoproizvodstva, SanktPeterburg: Alfa, 1996, tom 1, p. 365.

41 M.V. Kozhevnikov, Istoriia Sovetskogo Suda 1917-1956 gody, Moskva: Gosudarstvennoe Izdatel'stvo Iuridicheskoi literatury, 1957, p. 50.

42 Petukhov, pp. 167-172.

43 Ibid. p. 174.

44 Cited by Petukhov, p. 174.

45 Kozhevnikov, p. 97.

46 Petukhov, p. 187.

47 Kozhevnikov, p. 244-245.

48 Ibid. 245.

49 H.J. Berman and M. Kerner, Documents on Soviet Military Law \& Administration, Cambridge: Harvard University Press, 1958, p. 126.

50 Kozhevnikov, p. 297.

51 Polozhenie o voennykh tribunalakh, approved by the Law of 25 December 1958, in Sbornik zakonov SSSR i ukazov Prezidiuma Verkhovnogo Soveta SSSR, 1938-1967, tom 2, Moskva: Izd-vo "Izvestiia Sovetov Deputatov Trudiashchikhsia SSSR, 1968, p. 520. A.S. Koblikov, A.G. Mazalov, V.E. Smol'nikov, Nauchno-prakticheskii komentarii k Polozheniiiu o voennykh tribunalakh, Moskva: Gos. Izd-vo Iuridicheskoi literatuty, 1960, p. 13.

52 A.S. Koblikov, A.G. Mazalov, V.E. Smol'nikov, p. 17.

53 Ibid. p. 17.

54 Ibid. p. 19.

55 Vedomosti Verkhovnogo Soveta SSSR, 1980, \# 27, art. 546.

56 Ibid. p. 571.

57 Federal' nyi zakon ot 2 ianvaria 2000 g. \# 37-FZ “O narodnykh zasedateliakh federal'nykh sudov obshchei iurisdiktsii Rossiiskoi Federatsii”.

58 N.P. Kovalev, "Lay Adjudication of Crimes in the Commonwealth of Independent Sates: An Independent and Impartial Jury or a 'Court of Nodders'?”, The Journal of East European Law, \# 11, 2004, pp. 126-127.

59 The list of crimes which can be tried by juries includes aggravated murder, aggravated rape, aggravated kidnapping, terrorism, hostage-taking, hijacking of an aircraft, a sea-going ship, or a railway train, high treason, espionage, armed rebellion, the development, manufacture, stockpiling, acquisition or sale of weapons of mass-destruction, genocide, mercenarism and assaults on persons or institutions enjoying international protection. UPK RF, art. 31(3) and 31(6).

60 The Baltic Fleet Court (Baltiiskii flotskii voennyi sud) is located in Kaliningrad, the Northern Fleet Court (Severnyi flotskii voennyi sud) - in Severomorsk, the Pacific Ocean Fleet Court (Tikhookeanskii voennyi sud) - in Vladivostok, the Third District Military Court (Tretii okruzhnoi voennyi sud) - in Moscow, the East-Siberian District Military Court (Vostochno-Sibirskii okruzhnoi voennyi sud) - in Chita, the Far East District Military Court (Dal'nevostochnyi okruzhnoi voennyi sud) - in Khabarovsk, the West-Siberian District Military Court (Zapadno-Sibirskii okruzhnoi voennyi sud) - in Novosibirsk, the Leningrad District Military Court (Leningradskii okruzhnoi voennyi sud) - in Saint-Petersburg, the Moscow District Military Court (Moskovskii okruzhnoi voennyi sud) - in Moscow, the Volga District Military Court (Privolzhskii okruzhnoi voennyi sud) - in Samara, the North Caucasus District Military Court (Severo-Kavkazskii okruzhnoi sud) - in Rostov-on-Don and the Ural District Military Court (Ural'skii okruzhnoi sud) - in Yekaterinburg. The full list of garrison 
and district (fleet) military court with contact information is available on the official website of the Russian Supreme Court at http://www.supcourt.ru/courts_m.php?id=28\#a.

61 It is obviously not a coincidence that the system of federal districts introduced by President Putin in 2000 almost exactly corresponds with the structure of military districts with the exception of Volga-Ural military district which is divided into Volga and Ural federal districts. 62 Ibid.

63 Doklad predsedatelia Voennoi kollegii Verkhovnogo Suda Rossiiskoi Federatsii general-maiora iustitsii A.Ia. Petrochenkova, seminar-soveshchanie predsedatelei okruzhnykh (flotskikh) voennykh sudov, 2 February 2005, http://www.supcourt.ru/print_page.php? $\mathrm{id}=2546$.

64 The jurisdiction of Moscow District Military Court includes City of Moscow and the following provinces of Central Russia: Moscow, Kaluga, Tula, Riazan', Kostroma, Iaroslavl', Tver', Vladimir, Smolensk, Briansk, Orel, Tambov, Lipetsk, Kursk, Voronezh, Belgorod, Ivanovo http://www.movs.ru/about/urisdikzia.php?print=Y.

65 E.V. Zubov, "Prisiazhnye v voennom sude: pervye shagi, novye voprosy", Vestnik Moskovskogo okruzhnogo voennogo suda, \# 2, 2006, http://www.movs.ru/about/ vestnik/2_2006/shagi_zubov.php.

66 Soveshchanie po itogam raboty, http://www.movs.ru/about/press_sluzba/news/detail.php? $\mathrm{ID}=1276$.

67 This information was obtained from my personal communication with academics from Khabarovsk.

68 See more on this phenomenon of post-Soviet military culture F. Daucé and E. SiecaKozlowski (Eds), Dedovshchina in Post-Soviet Military. Hazing of Russian Army Conscripts in a Comparative Perspective, Stuttgart: Ibidem-Verlag, 2006; and Issue 1 of The Journal of Power Institutions in Post-Soviet Societies, http://www.pipss.org/sommaire190.html.

69 Kassatsionnoe opredelenie Voennoi Kollegii Verkhovnogo Suda RF ot 19 avgusta 2004 g. \# 5-43/04 (case of A.); Kassatsionnoe opredelenie Voennoi Kollegii Verkhovnogo Suda RF ot 13 noiabria $2003 \mathrm{~g}$. No. 5-62/03 (case of S.).

70 Kassatsionnoe opredelenie Voennoi Kollegii Verkhovnogo Suda Rossiiskoi Federatsii ot 19 oktiabria 2004 g. No. 2-054/02 (case of Tarasov, Bal' \& Repnikov).

71 Kassatsionnoe opredelenie Voennoi Kollegii Verkhovnogo Suda ot 26 avgusta 2004 g. \# 1-011/03 (case of Ulman, Kalaganskii, Voevodin \& Perelevskii); Kassatsionnoe opredelenie Voennoi Kollegii Verkhovnogo Suda Rossiiskoi Federatsii ot 11 noiabria 2004 g. \# 5-64/04 (case of Khudiakov \& Arakcheev); Kassatsionnoe opredelenie Voennoi Kollegii Verkhovnogo Suda Rossiiskoi Federatsii ot 25 aprelia 2006 g. \# 5-64/04 (case of Khudiakov \& Arakcheev).

72 Kassatsionnoe opredelenie Voennoi Kollegii Verkhovnogo Suda Rossiiskoi Federatsii ot 15 iulia 2004 g. \# 6-35/04 (case of Sagitdinov).

73 Kassatsionnoe opredelenie Voennoi Kollegii Verkhovnogo Suda Rossiiskoi Federatsii ot 20 ianvaria 2004 g. \# 5-48/03 (case of R., B., G. \& N.); Kassatsionnoe opredelenie Voennoi Kollegii Verkhovnogo Suda Rossiiskoi Federatsii ot 10 marta 2005 g. \# 5-27/04 (case of H.). 74 Case of Skotnikov et al. http://www.movs.ru/about/press_sluzba/news/detail.php?ID=968. 75 Case of Boev http://www.movs.ru/about/press_sluzba/news/detail.php?ID=1171.

76 Case of Doronin http://www.movs.ru/about/press_sluzba/news/detail.php?ID=1245.

77 See more on mass reversals of acquittals by the Supreme Court S.C. Thaman, Jury Trial and Adversary Procedure in Russia: Reform of Soviet Inquisitorial Procedure or Democratic Window-Dressing? In G.B. Smith and R. Sharlet (eds.), Russia and Its Constitution: Promise and Political Reality, Leiden: Brill N.V., 2008, pp. 141-180.

78 The Constitution of the Russian Federation, http://www.departments.bucknell.edu/russian/ const/constit.html.

79 Ibid. Art. 47(2).

80 Ibid. Art. 123(4).

81 Section 11(f) of the Canadian Charter of Rights and Freedoms states: "Any person charged with an offence has the right... except in the case of an offence under military law tried before a military tribunal, to the benefit of trial by jury where the maximum punishment for the offence is imprisonment for five years or a more severe punishment". Canadian Charter of Rights and Freedoms, Constitution Act, 1982, http://laws.justice.gc.ca/en/charter/\#droits. 
82 National Defence Act, R.S., 1985, c. N-5, http://laws.justice.gc.ca/en/ShowDoc/cs/N-5/// en?page $=1 \&$ isprinting $=$ true.

83 United States Code, Title 10, Subtitle A, Part II, Chapter 47 http://www4.law.cornell.edu/ uscode/10/stApIIch47.html.

84 See for example, Armed Forces Act 1996, Chapter 46, http://www.opsi.gov.uk/acts/ acts1996/ukpga_19960046_en_1.

85 It should be noted that although the Russian Federation imposed moratorium on the death penalty after it joined the Council of Europe and signed Protocol 6 to the European Convention on Human Rights in 1997 the Protocol has not been ratified since then. Moreover the Russian Federation has not even signed Protocol 13 to the European Convention, concerning the abolition of the death penalty in all circumstances. The death penalty provisions were not excluded from the Criminal Code, which stipulates this punishment for five serious offences including aggravated murder, encroachment on the life of a statesman or a public figure, encroachment on the life of a person administering justice or engaged in a preliminary investigation, encroachment on the life of an officer of a law-enforcement agency, and genocide. Ugolovnyi Kodeks Rossiiskoi Federatsii, 13 June 1996, \# 63-FZ (with amendments as of 21 July 2005).

86 In re the Constitutionality of a number of provisions of the Federal Constitutional Law "On military courts", federal laws "On jurors of federal courts of general jurisdiction in the Russian Federation", "On the introduction of Code of Criminal Procedure" and Code of Criminal Procedure, in Connection with Petitions from the President of Chechen Republic, North Caucasus District Military Court and Complaint of Citizen K.G. Tuburova. Rossiiskaia Gazeta, 12 April 2006, \# 4041, http://www.rg.ru/2006/04/12/a105376.html.

87 Chechnya is the only subject of the Russian Federation where trial by jury has not been introduced yet. The federal Government and Parliament postponed its introduction twice in 2002 and in December 2006. According to the Law of 27 December 2006 provisions of Code of Criminal Procedure concerning trial by jury should be implemented in Chechnya not before January 1, 2010.

88 U.S. Constitution, Amendment VI.

89 U.S. Constitution, Art. III section 2.

90 Ex parte Milligan, 71 U.S. 2, 123 (1866). This decision of the court, however, was criticized by some American scholars for its improper analysis of "the constitutional and historical underpinnings of the right to trial by jury and its application to the military". See, for example, G.P. Glazier, "He Called for His Pipe, and He Called for His Bowl, and He Called for His Members Three - Selection of Military Juries by the Sovereign: Impediment to Military Justice", Military Law Review, Vol. 157, pp. 14-23, 108-109.

91 Presently there are eighty-four subjects of the Russian Federation and only 11 district military courts located in different subject of the RF.

92 Courts Act 1971, C. 23, http://www.statutelaw.gov.uk/content.aspx? activeTextDocId=1403955.

93 Kassatsionnoe opredelenie Voennoi Kollegii Verkhovnogo Suda ot 19 avgusta 2004 g. \# 5-43/04.

94 According to Ukaz Prezidenta RF ot 27 iiulia 1998 g. \# 900 "O voenno-administrativnom delenii Rossiiskoi Federatsii”, art. 2 North Caucasus military district includes besides Chechnya twelve following provinces: Republic of Adygeia, Astrakhan province, Republic of Dagestan, Republic of Ingushetiia, Kabardino-Balkar Republic, Republic of Kalmykiia, Karachai-Cherkess Republic, Krasnodar Region, Republic of North Osetiia, Stavropol' Region, Rostov Province, and Volgograd Province.

95 Ibid., art. 1.

96 Case of Cooper v. the United Kingdom, Application no. 48843/99, 16 December 2003, para. 117.

97 Iu.I. Stetsovskii, Sudebnaia vlast’, Moskva: Izd-vo “Delo”, 1999, pp. 279-282, 289.

98 I. Smirnova, "Sudebnaia vlast' - tret'ia vlast', ili pochemu sud'iam zakony ne pisany?", Pravozashchitnik, \# 2, 2000, http://www.hro.org/editions/hrdef/200/0204.htm.

99 Svedeniia o rabote sudov obshchei iurisdiktsii za 12 mesiatsev 2007 goda, http:// cdep.sudrf.ru/uploaded-files/statistics/12\%20мес\%202007г.xls.

100 Vserossiiskaia perepis' naseleniia 2002 goda, http://www.perepis2002.ru/ct/doc/ TOM_04_03.xls. 
101 Attitude of Chechen community towards the Russian military perhaps can be compared with attitudes of Palestinians towards Israeli Defence Forces, which some Palestinian organizations branded "Israeli Occupation Forces", or with public opinion of Iraqi people, especially Sunnis, about US-led Forces. See The Palestinian Center for Human Rights, Assassination of Palestinians. An Israeli Official Policy. Report on extra-judicial killings committed by the Israeli Occupation Forces 29 September 2003 - 30 April 2004, June 2004, http://www.pchrgaza.org/files/Reports/English/2005/kiiling7.pdf. Program on International Policy Attitudes, The Iraqi Public on U.S. Presence and the Future of Iraq, 27 September 2006 http://www.worldpublicopinion.org/pipa/pdf/sep06/Iraq_Sep06_rpt.pdf.

102 A. Trofimov, "Chechenskii sindrom kak iuridicheskaia kolliziia", Nezavisimaia gazeta, 14 October 2005, http://www.ng.ru/politics/2005-10-14/2_kartblansh.html.

103 Convention for the Protection of Human Rights and Fundamental Freedoms of 4 Nov. $1950 \mathrm{http}: / /$ conventions.coe.int/Treaty/en/Treaties/Html/005.htm.

104 International Covenant on Civil and Political Rights Adopted and opened for signature, ratification and accession by General Assembly resolution 2200A (XXI) of 16 December 1966, http://www.unhchr.ch/html/menu3/b/a_ccpr.htm.

105 Universal Declaration of Human Rights, adopted and proclaimed by General Assembly resolution 217 A (III) of 10 December 1948, http://www.un.org/Overview/rights.html.

106 L. Nikitina, "Dosudebnyi prigovor", Vremia Novostei, \# 222, 29 November 2005, http:// www.vremya.ru/print/140046.html.

107 According to Vidmar "[a]1l common law jury systems retain change of venue as a remedial measure where there is a concern that the jury pool may be tainted from media publicity or from interpersonal sources of tainting when the crime is of particular concern to large segments of the community". N. Vidmar, "A Historical and Comparative Perspective on the Common Law Jury”, in N. Vidmar (ed.), World Jury Systems, New York: Oxford University Press, 2000, p. 40.

108 U.S. Federal Rules of Criminal Procedure, Rule 21 Transfer for Trial, http:// www.law.cornell.edu/rules/frcrmp/index.html\#toc.

109 Ibid. notes of advisory committee to Rule 21, http://www.law.cornell.edu/rules/frcrmp/ NRule21.htm.

110 V.R. Shahani, "Change the Motion, Not the Venue: A Critical Look at the Change of Venue", American Criminal Law Review, \# 42, p. 93.

111 U.S. v. McVeigh, 153 F.3d 1166, C.A.10 (Colo.), 1998.

112 UPK RF, art. 35 part 1.

113 S.A. Pashin, “Zakliuchenie po materialam sudebnogo protsessa po delu E.A. Ul'mana i dr.", 5 July 2004, http://www.neps.ru/node/1103.

114 S.C. Thaman, "Jury Trial and Adversary Procedure in Russia: Reform of Soviet Inquisitorial Procedure or Democratic Window-dressing?", in G.B. Smith and R. Sharlet (eds.), Russia and Its Constitution: Promise and Political Reality, Leiden: Koninklijke Brill NV, 2008, pp. 141-180.

\section{References}

Electronic reference

Nikolai P. Kovalev, « Trial by Jury in Russian Military Courts », The Journal of Power Institutions in Post-Soviet Societies [Online], Issue 8 I 2008, Online since 14 July 2008, connection on 02 March 2012. URL : http://pipss.revues.org/1533

\section{Author}

Nikolai P. Kovalev

Social Sciences and Humanities Research Council of Canada Postdoctoral Fellow at the Centre for European, Russian and Eurasian Studies of the University of Toronto

\section{Copyright}

Creative Commons License 
This text is under a Creative Commons license : Attribution-Noncommercial-No Derivative Works 2.0 Generic

\section{Abstract}

One of peculiar features of the military criminal justice system in Russia is that in some cases military defendants may apply for trial by jury. Unlike the existing U.S. court-martial jury and the Russian military jury of the early 1900s (World War I period) which were comprised of the members of the armed forces, in modern Russia jurors trying military defendants are civilians. This article aims to provide a brief history of military jury in Russia and identify issues of independence and impartiality in Russian military courts with participation of lay decision-makers. In particular, the article will analyze two high-profile cases which resulted in acquittals of Russian officers accused of killing several Chechen civilians during counterterrorist operations in Chechnya.

Keywords : Chechnya, Russia, Trials by Jury, Military Justice 